\title{
HUBUNGAN SENSE OF HUMOR GURU DENGAN MOTIVASI BELAJAR SISWA DI SMA NEGERI 1 WATOPUTE
}

\section{RELATIONSHIP BETWEENTEACHER'SSENSE OF HUMOUR WITH STUDENT LEARNING MOTIVATION IN SMAN 1 WATOPUTE}

\author{
Desi Asriani', Aspin², \& Yuliastri Ambar Pambudhi \\ Program Studi Psikologi \\ Fakultas Keguruan Dan Ilmu Pendidikan, Universitas Halu Oleo \\ Desiasriwani@gmail.com¹, Aspin.psi@gmail.com²,Yul_psy@yahoo.co.id ${ }^{3}$
}

\begin{abstract}
ABSTRAK : Peran seorang guru adalah untuk memberikan keteladanan, pengalaman serta ilmu pengetahuan kepada siswa. Guru dapat menarik perhatian siswa dengan memiliki sense of humor didalam kelas. Guru juga berperan untuk menumbuhkan atau memberikan motivasi belajar kepada siswa agar belajar dengan baik. Penelitianinibertujuan untuk mengetahui hubungan antara Sense Of Humor Guru dengan Motivasi Belajar Siswa Di SMAN 1 Watopute. Penelitian ini termasuk jenis penelitian kuantitatif dengan desain korelasional. Tahapan penelitian dengan screening terhadap 34 guru untuk menentukan guru yang memiliki sense of humor. Terdapat 6 guru dengan jumlah siswa yang diajar adalah 311 siswa yang menjadi populasi. Pengambilan sampel dalam penelitian ini menggunakan teknik simple random sampling, sampel diambil $25 \%$ dari jumlah populasi, sehingga didapatkan sampel 78 siswa. Hasil analisis korelasi product moment menunjukkan bahwa terdapat hubungan positif yang sangat signifikan antara sense of humor guru dengan motivasi belajar siswa di SMAN 1 Watopute $(p=0,000<0,01)$ dan $r=0,401$ yang artinya semakin tinggi sense of humor guru maka akan semakin tinggi pula motivasi belajar siswa. Tingkat kekuatan hubungan antar variabel berada pada tingkat sedang.
\end{abstract}

Kata Kunci : Sense Of Humor, Motivasi Belajar, Siswa.

ABSTRACT : The role of a teacher is to provide an example, experience and knowledge to students. The teacher can attract students' attention by having a sense of humour in the classroom. The teacher also has a role to foster or motivate students to learn well. This research aimed to determine the relationship between teacher's sense of humour with student learning motivation at SMAN 1 Watopute. This research is quantitative research with correlational design. 34 teacherswere screened to determine teachers who have a sense of humour. There are 6 teachers with 311 students being the population in this research. Thisresearch using simple random sampling technique, the sample was taken $25 \%$ of the total population, so that a sample of 78 students was obtained. The results of the product moment correlation analysis showed that there was a very significant positive relationship between teacher's sense of humour with student learning motivation at SMAN 1 Watopute $(p=0,000$ $<0.01)$ and $r=0.401$ which means that the higher the teacher's sense of humour,the motivation of student learning will also be higher. The level of strength of the relationship between variables is at a moderate level.

Keywords : Sense Of Humour, Learning Motivation, Students 


\section{Pendahuluan}

Mendidik, mengajar dan melatih anak didik merupakan tugas guru sebagai suatu profesi.Oleh karena itu, guru dituntut untuk mengembangkan profesional diri sesuai dengan perkembangan ilmu pengetahuan dan teknologi. Proses belajarmengajar akan senantiasa merupakan proses kegiatan interaksi antara dua unsur manusiawi, yakni siswa sebagai pihak yang belajar dan guru sebagai pihak yang mengajar, dengan siswa sebagai subjek pokok yang ingin meraih cita-cita, memiliki tujuan dan kemudian ingin mencapainya secara optimal (Sardiman, 2004).

Peran guru disekolah sangatlah penting, artinya guru sebagai perantara dalam usaha untuk memperoleh perubahan tingkah laku siswa. Berhasil tidaknya proses belajar disekolah akan banyak bergantung pada guru yang mampu memainkan peranan tersebut. Untuk itu seorang guru harus benar-benar menguasai prinsip-prinsip belajar serta menguasai materi yang akan diajarkannya. Peran guru merupakan bagaimana usaha yang dilakukan untuk menumbuhkan atau memberikan motivasi kepada siswa agar siswa dapat belajar dengan baik maka diperlukan motivasi yang baik.

Motivasi merupakan faktor penggerak maupun dorongan yang dapat memicu timbulnya rasa semangat.Sardiman (2004) mendefenisikan motivasi sebagai keseluruhan daya penggerak di dalam diri siswa yang menimbulkan kegiatan belajar, yang menjamin kelangsungan dari kegiatan belajar dan yang memberikan arah pada kegiatan belajar, sehingga tujuan yang dikehendaki oleh subjek belajar itu dapat tercapai.

Dalam belajar, tingkat ketekunan siswa sangat ditentukan oleh adanya motif dan kuat lemahnya motivasi belajar yang ditimbulkan motif tersebut.Motif belajar seorang siswa itu lebih dari satu atau bersifat majemuk. Seorang siswa yang belajar dengan rajin biasanya karena mempunyai motif ingin menuntut ilmu, ingin mendapat nilai yang bagus dan ingin lulus ujian. Jadi semakin banyak motif yang ada pada diri seorang siswa akan semakin kuatlah motivasi belajarnya (Hakim, 2010).

Hasil wawancara pada salah satu guru di SMA Negeri 1 Watopute pada tanggal 11 Oktober 2019 yang menyatakan tentang pentingnya pemberian motivasi di dalam kelas, guru tersebut mengatakan bahwa guru harus pandai-pandai untuk membuat siswa termotivasi di dalam kelas agar siswa dapat menjadi aktif dalam belajar dan dapat mudah menguasai materi, akan percuma jika seorang guru menjelaskan dengan baik di depan kelas jika siswa tidak termotivasi untuk belajar. Berdasarkan pernyataan tersebut, guru mengakui bahwa motivasi belajar memang penting ada pada diri siswa. Motivasi belajar yang kurang akan menyebabkan siswa tidak memiliki semangat belajar, sehingga apa yang diajarkan oleh guru kepada siswa menjadi sia-sia. Sardiman (2004) mengatakan bahwa dengan adanya usaha yang tekun dan terutama didasari adanya motivasi, maka seorang yang belajar itu dapat melahirkan prestasi yang baik.

Seorang guru harus berkualitas karena guru merupakan pengembang ilmu pengetahuan dan panutan bagi siswanya, maka guru harus sempurna dimata siswanya tidak hanya secara teori tetapi secara praktik juga. Menurut Pianda (2018) semakin meningkatnya kualitas seorang guru maka diharapkan siswa yang menjadi peserta didik dalam proses pembelajaranakan meningkatkan kualitasnya. Jadi, untuk meningkatkan kualitasnya seorang guru harus memiliki keterampilan yang dapat menarik perhatian siswa, seperti adanya selera humor guru didalam kelas. 
Menurut Wiyanto (2006) memiliki selera humor merupakan modal personal yang sangat berharga sekaligus dapat menjadi daya pikat tersendiri di mata siswanya. Selera humor guru sangat berguna dalam upaya menciptakan iklim kelas dan pengembangan proses pembelajaran yang lebih sehat dan menyenangkan. Dan yang paling penting, dengan selera humor yang dimilikinya, seorang guru akan menunjukkan bahwa dia adalah sosok orang yang memiliki kepribadian dan mental yang sehat, dapat menikmati hidup, serta mampu menjalani kehidupan karirnya secara wajar, tanpa stres.

Seorangguru dikatakan memiliki selera humor apabila guru tersebut dapat merubah keadaan menjadi seru dan menyenangkan bagi siswa-siswa tersebut. Guru memang harus berusaha bagaimanapun caranya agar siswa yang diajarinya termotivasi untuk belajar, karena motivasi siswa untuk belajar itu sangat penting. Jadi siswa menjadi aktif dalam belajar untuk menguasai materi pelajaran. Akan percuma jika seorang guru menerangkan dengan serius di depan kelas bila siswa tidak ada motivasi belajarnya.

Penelitian Hafzah (2014) yang menunjukkan adanya hubungan antara sense of humor guru dalam mengajar di kelas dengan motivasi belajar siswa di SMA Negeri 1Sangatta Utara. Hal ini menyatakan bahwa hubungan sense of humor dalam mengajar dikelas berpengaruh $44.3 \%$ pada motivasi belajar siswa, masih ada $45.7 \%$ faktor lain di luar sense of humor yang mempengaruhi motivasi belajar.

Seperti yang dikemukakan beberapa siswa pada tanggal 16 April 2019 bahwa mereka menyukai guru yang memiliki selera humor di dalam kelas alasannya agar mereka bisa rileks, tidak tegang, mata pelajaran yang dibawakan mudah untuk dimengerti, agar tidak mengantuk dan agar pelajarannya tidak membosankan.

Dari keterangan siswa tersebut. Siswa ternyata menyukai guru yang suka memberikan humor di dalam kelas. Pemberian humor di kelas dalam bentukbentuk tertentu akan menyebabkan siswa semangat untuk belajar. Namun, beberapa siswa menganggap selera humor guru akan dapat mengganggu pelajaran apabila humor yang dibuat guru menjadikan murid sebagai bahan tertawaan teman-temannya dan menganggap humor yang diberikan guru di dalam kelas sangat tidak bermanfaat.

Melihat fakta yang demikian itu, peneliti tertarik untuk melakukan penelitian korelasi antara sense of humor yang dimiliki guru dengan motivasi belajar siswa dalam proses pembelajaran, yang kemudian diberi judul "Hubungan Sense of humor guru dengan motivasi belajar siswa di SMA Negeri 1 Watopute Kabupaten Muna".

Berdasarkan uraian diatas tujuan penelitian ini adalah untuk mengetahui hubungan sense of humor guru dengan motivasi belajar siswa di SMA Negeri 1 Watopute. Manfaat penelitian ini terdiri dari:

1. Manfaat teoritis: penelitian ini diharapkan mempunyai manfaat yang bersifat pengembangan ilmu psikologi, khusunya di bidang psikologi pendidikan. Dari penelitian ini diharapkan memperkaya pengetahuan tentang sense of humor guru dalam proses belajar mengajar di kelas.

2. Manfaat praktis

a. Bagi sekolah

Untuk mengetahui motivasi belajar siswa, serta pihak sekolah juga dapat mengetahui hal-hal yang bisa mempengaruhi motivasi belajar siswa yaitu penggunaan humor di kelas, sehingga bisa dijadikan bahan pertimbangan untuk mengadakan peningkatan kemampuan guru yang 
berkaitan dengan interaksi di kelas guna meningkatkan motivasi belajar siswa.

b. Bagi guru

Untuk mengetahui bagaimana tanggapan siswa terhadap sense of humor guru, sehingga bisa dijadikan masukan bagi profesi guru tentang penting atau tidaknya penggunaan humor terkait dengan interaksi guru dan siswa di kelas.

c. Bagi masyarakat

Terutama bagi orang tua siswa agar mengetahui bahwa dengan adanya humor yang diberikan didalam kelas dapat membuat minat peserta didik di dalam kelas meningkat sehingga siswa dapat membuat prestasi yang membanggakan orangtuanya.

\section{Metode Penelitian}

Penelitian ini dilakukan di SMAN 1 Watopute yang terletak di Jalan poros Watuputih-Kosambi Kel. Wali, Kec. Watopute pada tanggal 12-13 November 2019. Jenis penelitian ini adalah penelitian kuantitatif.Desain penelitian yang digunakan adalah korelasional.

Defenisi operasional variable penelitian terdiri dari:

1. Sense of humor yaitu selera guru untuk menciptakan dan mengekpresikan humor dalam berinteraksi dengan siswa, guna mendukung pembelajaran dalam kelas. Selera humor guru mengandung perasaan senang kepada siswa tanpa membuat rasa sakit secara fisik maupun psikis terhadap siswa. Data mengenai sense of humorguru diperoleh dari skala psikologis yang disusun sendiri oleh peneliti.Sense of humor dalam penelitian ini diukur dengan menggunakan teori Thorson \& Powell (1991) yaitu produksi humor, rasa suka main-main atau imajinasi, Kemampuan menggunakan humor untuk tujuan sosial, Pengakuan pribadi akan humor, apresiasi lucu, dan penggunaan humor sebagai mekanisme adaptif. Semakin tinggi skor subjek skala sense of humor guru maka semakin tinggi pula tingkat sense of humor guru, begitu juga sebaliknya.

2. Motivasi belajar yaitu sesuatu yang membuat individu atau siswa melakukan kegiatan belajar yang didorong oleh hasrat untuk mencapai hasil belajar sebaik mungkin. Data mengenai motivasi belajar diperoleh dari skala psikologis yang disusun sendiri oleh peneliti. Motivasi belajar dalam penelitian ini diukur dengan menggunakan teori Uno (2011) yaitu adanya hasrat dan keinginan berhasil, adanya dorongan dan kebutuhan dalam belajar, adanya harapan dan cita-cita masa depan, adanya penghargaan dalam belajar, adanya kegiatan menarik dalam belajar,dan adanya lingkungan belajar yang kondusif, sehingga memungkinkan seorang siswa dapat belajar dengan baik. Semakin tinggi skor subjek skala motivasi belajar maka semakin tinggi pula tingkat motivasi belajar, begitu juga sebaliknya.

Tahapan dalam penelitian ini menggunakan screening terhadap 34 guru. Dengan hadil angket yang telah diberikan terdapat 6 orang guru yang memiliki selera humor dalam kelas, sehingga disimpulkan bahwa populasi dalam penelitian ini adalah siswa kelas X IIS, X MIA, XI IIS, XI MIA, XII MIA. Jadi populaisnya adalah sebanyak 311 siswa di SMA Negeri 1 Watopute. Pengambilan sampel dalam penelitian ini menggunakan teknik probability sampling yaitu teknik simple random sampling. Sampel diambil sebanyak 25\% dari jumlah populasi.Jadi jumlah siswa yang diambil 
sebagai sampel dalam penelitian ini adalah 78 siswa dari 311 siswa.

Metode pengumpulan data dalam penelitian ini dilakukan dengan metode skala. Jenis skala yang digunakan adalah jenis skala likert. Skala ini terdiri dari dua macam yaitu skala sense of humor dan motivasi belajar. Dalam penelitian ini, uji validitas yang akan digunakan adalah uji validitas isi. Untuk menguji validitas isi, peneliti meminta tiga orang professional untuk menilai instrumen yang telah dibuat. Professionalyang dimaksud merupakan tiga orang dosen psikologi. Ketiga orang professional diminta pendapatnya untuk mengecek kesesuaian aitem dan penilaian terhadap aitem yang telah dibuat oleh peneliti.Setelah dilakukan professional judgement, peneliti menganalisis hasil professional judgement menggunakan koefisien validitas isi Aiken's V.

Teknik realibilitas yang digunakan adalah teknik satu kali pengukuran atau disebut juga konsisten internal. Pengujian realibiltas dilakukan dengan menggunakan teknik koefisien alpha dari Cronbach. Dengan menggunakan SPSS windows 23.0.

Analisis yang digunakan dalam penelitian ini yaitu analisis inferensial, untuk mengetahui apakah data terdistribusi secara normal dan apakah jenis data tersebut linear, dengan tahapan sebagai berikut:

1. Uji Asumsi
a. Uji Normalitas: menggunakan teknik Kolmogrov Smirnov
b. Uji Linearitas: menggunakan Test For Linearity
c. Uji Hipotesis : menggunakan korelasi Product Moment Pearson.

\section{Hasil Penelitian dan Pembahasan Hasil Penelitian}

1. Uji Asumsi

a. Uji Normalitas

Tabel 1. Ringkasan hasil uji normalitas

\begin{tabular}{ccc}
\hline Variabel & $N$ & Signifikansi \\
\hline Sense of Humor & 78 & 0,278 \\
\hline Motivasi belajar & 78 & 0,298 \\
\hline
\end{tabular}

Berdasarkan hasil uji normalitas Sense of humor guru mendapatkan nilai signifikansi 0,278 dan Motivasi belajar siswa mendapatkannilai signifikasi 0,298. Nilai $\mathrm{p}=0,278$ dan $\mathrm{p}=0,298$ lebih besar dari $0,05 \quad(p>0,05)$. Sehingga dapat disimpulkan bahwa data Sense of humor guru dan motivasi belajar siswa terdistribusi normal.

b. Uji Linearitas

Tabel 2.Ringkasan hasil uji linearitas

\begin{tabular}{cc}
\multicolumn{2}{c}{ Tabel 2.Ringkasan hasil uji linearitas } \\
\hline Sense of Humor & $\begin{array}{c}\text { Sig. Deviation from } \\
\text { linearity }\end{array}$ \\
\cline { 1 - 2 } Motivasi belajar & 0.675 \\
\hline
\end{tabular}

Berdasarkan hasil uji linearitas data sense of humor guru (X) terhadap motivasi belajar siswa (Y) diperoleh nilai sig 0,675 ( $\mathrm{p}>0,05)$ maka dapat dikatakan bahwa variabel sense of humor guru terhadap motivasi belajar mempunyai hubungan yang linear.

2. Uji Hipotesis

Pengujian hipotesis bertujuan untuk membuktikan ada tidaknya hubungan antara sense of humor guru dengan motivasi belajar siswa di SMA Negeri 1 Watopute. Berdasarkan hasil analisis data yang telah dilakukan sebagai berikut: 
a. Uji Korelasi Pearson Product Moment

Tabel 3. Ringkasan hasil uji korelasi

\begin{tabular}{ccccc}
\hline Variabel & $N$ & Korelasi & Sig \\
\hline Sense of Humor & 78 & $.401^{* *}$ & 0.000 \\
\hline Motivasi belajar & 78 & $.401^{* *}$ & 0.000 \\
\hline
\end{tabular}

Korelasi antara sense of humor denganmotivasi belajar dengan $\mathrm{N}=78$ didapatkan hasil koefisien korelasi (r) yaitu 0,401 dengan taraf sig. 0,000 $(<0,01)$ dimana nilai signfikan $<0,01$ yang artinya terdapat hubungan yang sangat signifikan antara sense of humor guru dengan motivasi belajar.

Tabel 4. Hubungan variabel

Interval Koefisien Tingkat Hubungan

$\begin{array}{lc}0.00-0.199 & \text { Sangat Rendah } \\ 0.20-0.299 & \text { Rendah } \\ 0.30-0.399 & \text { Sedang } \\ 0.40-0.499 & \text { Kuat } \\ 0.50-0.599 & \text { Sangat Kuat }\end{array}$

Karena nilai koefisien korelasi terletak diantara 0,40-0,599 tergolong kepada korelasi yang sedang. Jadi dengan nilai koefisien korelasi $=0,401$ dapat disimpulkan bahwa hubungan kedua variabel sense of humor guru dengan motivasi belajar siswa tergolong sedang.

\section{Pembahasan}

Penelitian ini dilakukan dengan tujuan untuk mengetahui hubungan sense of humor guru dengan motivasi belajar siswa di SMA Negeri 1 Watopute. Penelitian ini masih memiliki ketrbatasan yaitu keterbatasan waktu yang diberikan dalam mengisi skala yang dibagikan membuat subjek mengisi skala dengan tergesa-gesa, dan masih terdapat beberapa jawaban kuisioner yang tidak konsisten karena subjek yang cenderung tidak konsisten terhadap jawaban kuisioner. Pada penelitian ini menggunakan 78 siswa sebagai sampel penelitian. Hasil dari penelitian diperoleh angka koefisien korelasi $\quad\left(\mathrm{r}^{2}\right) \quad 0,401 \quad$ dengan tarafsig. $0,000(\mathrm{p}<0,01)$. Hasil koefisien korelasi tersebut menunjukkan adanya hubungan yang positif, artinya semakin tinggi sense of humor guru maka semakin tinggi motivasi belajar siswa pada siswa SMA Negeri 1 Watopute. Hipotesis pada penelitian ini dapat diterima yakni ada hubungan yang sangat signifikan antara sense of humor guru dengan motivasi belajar siswa di SMA Negeri 1 Watopute.

Hasil penelitian ini didukung oleh Hafzah (2014) pada 90 responden dimana hasil penelitiannya yang menyatakan bahwa terdapat hubungan yang sangat signifikan antara sense of humor guru dengan motivasi belajar siswa kelas XI SMA NEGERI 1 Sanggatta Utara dengan nilai koefisien korelasi 0,443, dan penelitian yang dilakukan oleh Rosyidah (2015) dengan 57 responden, bahwa berdasarkan analisis korelasi terdapat hubungan sense of humorguru dengan motivasi belajar PAI di SMPN 2 Beji kabupaten Pasuruan”.

Salah satu faktor yang dapat meningkatkan motivasi belajar adalah dengan adanya sense of humor guru, sebagaimana yang dikemukakan oleh Nilson (dalam Martin, 2007) yang menyatakan bahwa humor merupakan alat belajar yang penting, karena secara efektif dapat membawa seseorang agar mendengarkan pembicaraan dan merupakan alat persuasi yang baik. Hal yang sama juga terlihat saat guru menggunakan humor untuk menarik perhatian siswa dalam pembelajaran. Sehingga perhatian siswa terarah pada penjelasan guru dan bisa kembali fokus pada pembelajaran yang sedang berlangsung di dalam kelas. 
Cooper dan Swaf (dalam Darmansyah 2009) menyatakan bahwa humor seorang guru mendorong anak-anak untuk selalu ceria dan gembira serta tidak akan lekas merasa bosan atau lelah. Oleh karena itu ketika suasana kebosanan sudah mulai tampak di dalam kelas, hendaknya guru segera berupaya untuk mengembalikannya ke suasana yang menyenangkan dan rileks. Sesuai dengan hasil wawancara dengan $\mathrm{R}$ yang merupakan salah seorang guru yang menurut para siswa memiliki selera humor di dalam kelas, dia mengatakan bahwa menyisipkan humor dalam proses pembelajaran dapat menyegarkan suasana kelas bisa lebih hidup, juga menghilangkan ketegangan saat belajar, apalagi saat jam pelajaran terkahir karena siswa terlihat sangat lelah juga merasa bosan.

Ekspresi wajah guru yang ceria di dalam kelas merupakan salah satu kesan humoris yang dapat diperlihatkan oleh guru kepada siswa. Kesan yang ditangkap oleh siswa bahwa guru mereka orang humorisdapat ditunjukkan dengan sikap guru yang murah senyum, sehingga dapat berpengaruh positif juga terhadap siswa. Sebaliknya, guru yang jarang sekali kelihatan tersenyum oleh siswanya akan menyebabkan mereka kaku saat berinteraksi dengan guru sehingga berdampak negatif dalam interaksi antara guru dan siswa baik di luar proses pembelajaran maupun di dalam proses pembelajaran, salah satunya yaitu kurangnya motivasi siswa terhadap pembelajaran yang menyebabkan tidak efektifnya proses pembelajaran.

Dari hasil penelitian yang dilakukan, maka hipotesis yang diajukan dalam penelitian ini diterima yakni terdpat hubungan yang sangat signifikan antara sense of humor guru dengan motivasi belajar siswa di SMA Negeri 1 Watopute, dengan angkakoefisien korelasi 0,401 berarti ada hubungan positif artinya semakin tinggisense of humor guru maka semakin tinggi pula motivasi belajar siswa di SMA Negeri 1 Watopute.

\section{Kesimpulan dan Saran Kesimpulan}

Berdasarkan hasil penelitian yang telah dilakukan maka dapat disimpulkan bahwa terdapat hubungan yang sangat signifikan antara sense of humor guru dengan motivasi belajar siswa di SMA Negeri 1 Watopute. Interval koefisien tingkat hubungan juga terletak dalam kategori sedang karenanilai koefisien korelasi terletak diantara 0,40-0,599 tergolong kepada korelasi yang sedang. Jadi dengan nilai koefisien korelasi 0,401 dapat disimpulkan bahwa hubungan kedua variabel sense of humor guru dengan motivasi belajar siswa di SMA Negeri 1 Watopute tergolong sedang.

\section{Saran}

1. Bagi siswa Siswa diharapkan mempunyai motivasi belajar yang tinggi agar tujuan yang diinginkan siswa dapat tercapai. Siswa dapat mengambil hal positif tentang pemberian humor di kelas oleh guru yaitu untuk meningkatkan motivasi belajar siswa.

2. Bagi guru

Berdasarkan hasil penelitian ini dapat diketahui bahwa siswa SMA Negeri 1 Watopute memiliki motivasi belajar yang sedang, sehingga disarankan bagi guru untuk mempertimbangkan penggunaan humor dalam proses mengajar di kelas guna meningkatkan motivasi belajar siswa. Meskipun untuk meningkatkan motivasi belajar siswa bisa dipengaruhi oleh berbagai hal dan salah satunya adalah sense of humor guru. Oleh karena itu, diharapkan bisa membekali diri dengan humor-humor 
positif yang sekiranya dapat digunakan atau disisipkan dalam mendukung proses belajar mengajar di kelas. Akan tetapi, perlu diperhatikan pemberian humor tersebut tidak boleh berlebihan agar tidak mengganggu pelajaran.

3. Bagi sekolah

Pihak sekolah dapat mengetahui bahwa sense of humor guru dapat membantu mengatasi interaksi guru dan siswa di kelas menjadi baik. Oleh karena itu pihak sekolah dapat menjadikan wacana kepada guru bahwa sense of humor yang digunakan pada saat proses belajar-mengajar di kelas, dapat meningkatkan kemampuan interaksi guru terhadap murid di kelas, sehingga dapat mengoptimalkan proses pembelajaran khususnya untuk meningkatkan motivasi belajar siswa.

4. Bagi peneliti lain

Penelitian ini memberikan informasi bahwa sense of humor guru memiliki hubungan dengan motivasi belajar siswa di SMA Negeri 1 Watopute. Motivasi belajar tidak hanya dipengaruhi variabel sense of humor guru namun masih banyak di pengaruhi oleh variabelvariabel lain yang berkaitan dengan motivasi belajar. Oleh karena itu dimungkinkan peneliti selanjutnya melakukan penelitian dengan model yang lebih variatif.

\section{Daftar Pustaka}

Darmansyah. (2009). Pembelajaran menggunakan sisipan humor dalam mata pelajaran matematika. Jurnal Kependidikan, 10 (1), 31-41.
Hafzah. (2014). Hubungan sense of humor guru dalam mengajar di kelas dengan motivasi belajar siswa di SMA Negeri 1 Sanggatta Utara. Ejournal Psikologi, 16.

Martin, R. A. (2007). The pschology of humor: an integrative approach. Burlington: Elsevier Academic Press.

Pianda, D. (2018). Kinerja guru: kompetensi guru, motivasi kerja dan kepemimpinan kepala sekolah. Jawa Barat: CV Jejak.

Rosyidah, K. (2015). Hubungan sense of humor guru dengan motivasi belajar siswa PAI di SMP Negeri 1 BEJI Kabupaten Pasuruan. (Skripsi). Fakultas Tarbiyah dan Keguruan Universitas Islam Negeri Sunan Ampel Surabaya.

Sardiman.(2004).Interaksi dan motivasi belajar mengajar. Jakarta: PT Raja Grafindo Persada.

Thorson, J. A.,\& Powell, F.C. (1991).Measurement of sense of humor. pschological reports, 69, 691-701.

Uno, H. (2011). Teori motivasi dan pengukurannya. Jakarta: PT Bumi Aksara.

Wiyanto, A. (2006). Pelajaran bahasa dan sastra indonesia. Jakarta: Grasindo.

Hakim, T. (2010).Belajar secara efektif. Niaga Swadaya. 